\title{
Books by Our Readers
}

Why Public Service Matters: Public Managers, Public Policy, and Democracy Robert Durant

\section{Palgrave Macmillan}

From the publisher: Why Public Service Matters conveys the importance, purpose, and nobility of a career as a civil servant in the United States. It does so, however, with an unflinching eye on the realpolitik that drives public administration in America's 'compensatory state' and on the pitfalls for the republic of reformers' focus on bureaucratic rather than democratic administration. The book links the nation's ability to deal with contemporary policy problems with the strategic, tacti$\mathrm{cal}$, and normative quality of public management. In doing so, it offers newcomers a badly needed concise and accessible overview of the field. From its relentless historical, diagnostic, strategic, and normative focus, readers will gain an appreciation from each chapter for the challenges, choices, and opportunities facing public managers as they help advance a sense of common purpose informed by democratic constitutional values in twenty-first century America.

Robert Durant is professor of public administration and policy at American University, USA. He is the recipient of three lifetime awards for his contributions to public administration and policy research: the Dwight Waldo Award from the American Society for Public Administration, the John M. Gaus Award and Lectureship from the American Political Science Association, and the Charles H. Levine Memorial Award from the American Society for Public Administration and the National Association of Schools of Public Affairs and Administration.
Nonprofits and Advocacy: Engaging Community and Government in an Era of Retrenchment

edited by Robert J. Pekkanen, Steven Rathgeb Smith, and Yutaka Tsujinaka

Johns Hopkins University Press

From the Publisher: Should a nonprofit advocate for its mission and its constituents with a goal of affecting public policy? What are the limits of such advocacy work? Will such efforts fundamentally jeopardize nonprofit work? What can studies of nonprofit advocacy efforts reveal? Editors Robert J. Pekkanen, Steven Rathgeb Smith, and Yutaka Tsujinaka recognize the urgent need for relevant research and insight into these issues as direct and indirect government services are squeezed by federal cutbacks.

Nonprofits and Advocacy defines advocacy and clarifies the differences among advocacy, lobbying, political activity, and education, as well as advocacy measurements. Providing original empirical data and innovative theoretical arguments, this comparative study is organized into two parts. The first part focuses on local and national dimensions of nonprofit advocacy, and the second part looks at organizational politics and strategies. The conclusion considers basic questions about nonprofit advocacy and seeks to draw lessons from research efforts and practice.

Providing a critical look at the multidimensional roles and advocacy efforts of nonprofits, this volume will be valued by scholars, students, leaders, and activists-many of whom advocate for the interests of their organizations while delivering services to their organizations' constituents. The research is also relevant for policymakers involved in cross-sector public policy initiatives as they strive to provide more efficient public-private solutions to challenging governance issues.

Robert J. Pekkanen is an associate professor in the Henry M. Jackson School of International Studies and adjunct associate professor in the Department of Political Science at the University of Washington. Steven Rathgeb Smith is executive director of the American Political Science Association and affiliate professor in the Evans School of Public Affairs at the University of Washington. Yutaka Tsujinaka is the president-elect of the Japanese Political Science Association and a professor of political science in the Graduate School of Humanities and Social Sciences at the University of Tsukuba.
Advancing Electoral Integrity

Edited by Pippa Norris, Richard W. Frank, and Ferran Martinez i Coma

Oxford Uniersity Press

After Occupy: Economic Democracy for the
21st Century
Tom Malleson
Oxford University Press

Brazil: Reversal of Fortune

Alfred P. Montero

Polity Books

Building the Federal Schoolhouse: Localism and the American Education State

Douglas S. Reed

Oxford University Press

\author{
Buying the Vote: A History of Campaign \\ Finance Reform \\ Robert E. Mutch \\ Oxford University Press
}

Canadian Democracy from the Ground Up: Perceptions and Performance

Edited by Elisabeth Gidengil and Heather Bastedo

UBC Press

\section{Celebrity Politics \\ Mark Wheeler \\ Polity Books}
The Character of Democracy: How Institu- tions Shape Politics
Richad A. Clucas and Melody Ellis Valdini Oxford University Press

Collaborative Governance for Urban Revitalization: Lessons from Empowerment Zones Michael J. Rich and Robert P. Stoker Cornell University Press

Comparative Peace Processes

Jonathan Tonge

Polity Books

\section{Compassionate Communalism: Welfare and Sectarianism in Lebanon \\ Melani Cammett \\ Cornell University Press}

Courts, Codes, and Customs: Legal Tradition and State Policy toward International Human Rights and Environmental Law Dana Zartner Oxford University Press

\section{Creolizing Political Theory: Reading} Rousseau through Fanon Jane Anna Gordon Oxford University Press/Fordham University Press 
Curriculum and the Culture Wars: Debating the Bible's Place in Public Schools

Edited by Melissa Deckman and Joseph

Prud'homme

Peter Land International Academic

Publishers

Deliberative Democracy: Issues and Cases Edited by Stephen Elstub and Peter

McLaverty

Oxford University Press

Delivering the People's Message: The Changing Politics of the Presidential Mandate

Julia R. Azari

Cornell University Press

Democratic Transformation and Obstruction EU, US and Russia in the South Caucasus

Nelli Babayan

Routledge

Diplomatic Afterlives

Andrew Cooper

Polity Books

Drone Warfare

John Kaag and Sarah Kreps

Polity Books

Empires without Imperialism

Jeanne Morefield

Oxford University Press

The End of American World Order

Amitav Acharya

Polity Books

The Ethics of Immigration

Joseph Carens

Oxford University Press

Faith and the Founders of the American Republic

Edited by Daniel Dreisbach and Mark

David Hall

Oxford University Press

Fighting the End: The Pakistan Army's Way of War

C. Christine Fair

Oxford University Press

Fugitive Rousseau: Slavery, Primitivism, and Political Freedom

Jimmy Casas Klausen

Oxford University Press/Fordham

University Press

Gender, War and Conflict

Laura Sjoberg

Polity Books

Global Gangs

Edited by Jennifer M. Hazen and

Dennis Rodgers

Minnesota University Press
Gridlock: Why Global Cooperation Is Failing When We Need It Most

Thomas Hale, David Held, and Kevin

Young

Polity Books

The Gun Debate

Philip J. Cook and Kristin A. Goss

Oxford University Press

Latino Politics 2nd Edition

Lisa Garcia Bedolla

Polity Books

Liberalism and the Emergence of American Political Science: A Transatlantic Tale Robert Adcock

Oxford University Press

Lincoln and Liberty: Wisdom for the Ages

Edited by Lucas E. Morel

University Press of Kentucky

Mass Politics in Tough Times

Edited by Larry Bartels and Nancy

Bermeo

Oxford University Press

A Middle Class without Democracy:

Economic Growth and the Prospects for

Democratization in China

Jie Chen

Oxford University Press

Narrative Politics: Stories and Collective

Action

Frederick W. Mayer

Oxford University Press

Networks of Domination: The Social Foundations of Peripheral Conquest in International Politics

Paul K. MacDonald

Oxford University Press

Networks of Rebellion: Explaining Insurgent Cohesion and Collapse

Paul Staniland

Cornell University Press

Nuclear Desire: Power and the Postcolonial Nuclear Order

Shampa Biswas

University of Minnesota Press

Nuclear Strategy in the Modern Era

Vipin Narang

Princeton University Press

The Outrage Industry: Political Opinion

Media and the New Incivility

Jeffry M. Berry and Sarah Sobieraj

Oxford University Press

Privatizing the Polity

Holona LeAnne Ochs

SUNY Press
Protest Inc.: The Corporatization of Activism

Peter Dauvergne and Genevieve Lebaron Polity Books

The Politics of Non-State Social Welfare

Edited by Melani C. Cammett and Lauren

M. MacLean

Cornell University Press

The Politics of Uncertainty: Sustaining and Subverting Electoral Authoritarianism

Andreas Schedler

Oxford University Press

The Politics of Women's Health Care in the United States

Marian Lief Palley and Howard A Palley

Palgrave Macmillan

Public Policy Investment: Priority-Setting and Conditional Representation in British

Statecraft

Anthony Bertelli and Peter C. John

Oxford University Press

Radical Future Pasts: Untimely Political

Theory

Edited by Romand Coles, Mark

Reinhardt, and George Shulman

University Press of Kentucky

Red Skin, White Masks: Rejecting the Colonial Politics of Recognition

Glen Sean Coulthar

University of Minnesota Press

Religion and Democratization: Framing Religious and Political Identities in Muslim and Catholic Societies

Michael D. Driessen

Oxford University Press

Social Democratic America

Lane Kenworthy

Oxford University Press

Territorial Pluralism: Managing Difference in Multinational States

Edited by Karlo Basta, John McGarry, and Richard Simeon

UBC Press

Time to React: The Efficiency of International Organizations in Crisis Response

Heidi Hardt

Oxford University Press

Traveling Back: Toward a Global Political Theory

Susan McWilliams

Oxford University Press

Unbroken Government: Success and the Illusion of Failure in Policymaking

Wendy N. Whitman-Cobb

Palgrave Macmillan 